\title{
Career Construction Counseling With a Mid-Career Black Man
}

\author{
J. G. (Kobus) Maree
}

Department of Educational Psychology, University of Pretoria, Faculty of Education, Groenkloof Campus, Pretoria 0001, South Africa (e-mail: kobus.maree@up.ac.za).

\section{Abstract}

Career construction counseling for a mid-career Black man is examined. The author implemented a case study design and purposively selected the participant. The intervention and follow-up occurred over a period of 21 months, and the Career Construction Interview (CCI; Savickas, 2011a) was used to gather data. Savickas's 8-step strategy was followed to complete the participant's life portrait. After the intervention, the participant demonstrated an improved sense of self and willingness to deal more adaptively with careerlife-related challenges. More research is needed to determine the long-term effects of this kind of intervention and to show its applicability in group contexts.

Keywords: career construction counseling, Career Construction Interview, midcareer development, life themes, career adaptability

Traditional career theories may not provide a satisfactory basis for interventions aimed at dealing with constantly changing 21 st-century career environments, nor adequately address the needs of marginal workers (Savickas, 2013). Life design (Savickas et al., 2009) offers a viable conceptual framework for the development of new constructs for investigating working lives and understanding 21st-century change and its effect on people. This paradigm emphasizes identity rather than personality, career adaptability rather than maturity, stories in addition to scores, and action to help people navigate transitions during their lifetimes.

The fifth economic wave (Gurri, 2013) calls for an approach to career counseling that takes into account changes in the postmodern world of work - an up-to-date approach to help career counselors assist clients in navigating repeated career transitions. Such an approach would involve obtaining "subjective" data about clients in addition to "objective" test results, and interpreting and integrating the data to promote effective career counseling. Counselors would then be in a position to elicit clients' career-life stories, get clients to authorize these stories, and, eventually, help them move forward productively. In the present study, career construction was used 
as a theoretical and intervention framework for analyzing and interpreting a client's stories and own reality (Savickas, 2005, 2014).

\section{Career Construction Principles and Practices}

Underlying career construction theory (Hartung, 2013; Savickas, 2011a) is the notion of career as story (career-life story) and counselor characteristics, such as honesty, congruence, compassion, truthfulness, and mutual respect (Maree, 2013; Savickas, 2011a). Career construction theory (Savickas, 2005, 2011a) and self-construction theory (Guichard, 2009) are integral to the life-design paradigm (Savickas et al., 2009). Many career counselors today set out to help clients "hold" themselves in the face of growing discontinuity in the postmodern workplace. Clients have to be helped to express and listen to their career and life stories and draw on these stories when life imposes change upon them and when they have to make changes themselves. Career counselors strive to help clients identify their major life themes so they can use work to "heal" others and, in doing so, heal themselves. (Auto)biographicity thus relates to clients' ability to use their stories to hold themselves in times of change (Savickas, 2011a). The Career Construction Interview (CCI; Savickas, 2011a) is used to elicit client stories that help reveal their central life themes more accurately. The promotion of career adaptability is a key goal of career construction counseling.

\section{Career Adaptability}

The adaptability segment of career construction theory deals with career development tasks, role transitions, work traumas, and strategies for working through traumas and transitions (Savickas, 2012). Career adaptability is a psychosocial process that refers to people's readiness to manage transitions and changes and to construct themselves. Career construction counseling helps people make choices by enhancing their career adaptability in terms of concern for their work role, career, and future lives; control of their chosen career lives; curiosity regarding career-related opportunities and options; and confidence in making appropriate career-related choices (Savickas, 2012). Career construction counseling facilitates reflection (looking back on clients' thoughts and actions) to facilitate reflexivity (planning for the future) as an integral aspect of postmodern career counseling (M. L. Savickas, personal communication, July 12, 2014).

\section{Rationale and Purpose of the Study}

Fouad and Byars-Winston (2005) have called on career counseling practitioners and theorists to consider the idiosyncratic cultural contexts of racially diverse clients and 
their views on factors that promote and inhibit success. According to Pope (2011), the career counseling needs of culturally diverse clients are indeed receiving increased attention, but their position in the workplace is still substantially less favorable than that of their counterparts from dominant cultures (Ali, Fall, \& Hoffman, 2014). Despite some improvements in career counseling in recent years, members of minority groups (including people at a major socioeconomic disadvantage) are still receiving unequal career counseling (Maree, 2014).

Twenty years after the demise of apartheid in South Africa, the future of basic and higher education and the situation of workers, particularly Blacks in South Africa, looked bleak. The lack of career counseling, and the negative impact of that lack on tertiary training, reinforced the low social and economic position of poor and marginalized people in the country (of whom the vast majority are Black). Few students challenged by disadvantage receive career counseling in any form, and they often arrive at institutions of higher learning without a clear idea of what their prospective fields of study or careers actually entail (Maree, 2009; Maree \& Molepo, 2007). Subsequently, they often migrate from one field of study to another or end up in a job that adds little meaning to their lives and is not conducive to the design of a successful life.

Wijnberg (2013) explained that the career challenges faced by Black professionals have been well documented. Additionally, the growing shortage of skilled graduates (especially Blacks) against the background of high emigration figures is deeply worrying. Jobs for skilled professionals and unemployment rates are increasing steadily. Inequality, unemployment, and poverty seem even more widespread in South Africa today than before 1994, and the number of discouraged work seekers (Black workers in particular) is also steadily rising. The following linear progression among people challenged by major socioeconomic disadvantage is sustained: poor academic achievement $\rightarrow$ inability to enroll in sought-after fields of study that will help them find employment $\rightarrow$ inability to find employment $\rightarrow$ increase in rates of unemployment $\rightarrow$ lower economic growth $\wedge$ increase in likelihood of sociopolitical instability. Consequently, South Africa's future is under increasing threat. Ndebele (2013) also highlighted the fact that the situation in South Africa is clearly distinguishable along race-based fault lines: Roughly 50\% more White than Black students graduate every year. In addition, less than 5\% of Black and mixed-race students succeed in any form of tertiary training and education.

Watson (2013) contended that the traditional approach to career counseling has had a harmful effect, particularly on disadvantaged populations. Moreover, career theories (and their applications) have tended to be relevant only for "limited cultural, gender, and socioeconomic populations" (p. 4) and 
cannot be generalized to the majority of other groups. Against this background, it seems necessary to examine ways to address the career- choice-related concerns of Black people in South Africa at various levels.

Because this study sought to explore and understand the career adaptability of a participant and his experiences, it was situated within a qualitative, interpretive paradigm, which holds that knowledge is constructed and acquired through people's experiences and its view that knowledge and meaning are socially constructed. Furthermore, the premise of the study was the belief that a case-study approach based on an interpretive paradigm could best shed light on the unique stories of Black professionals challenged by disadvantage and, more particularly, on the belief that the CCI could be used successfully with such individuals and members of other minority groups. The main study aim was to answer the following questions:

1. How can the CCI contribute to changes in the sense of self of a mid-career Black person?

2. How can career counselors use the CCI to complete clients' life portraits and thereby help them assume personal authorship of their career and life stories?

3. Which change-related themes emerged by means of thematic analysis of the conversations with the participant?

4. What is the impact of the specific career counseling intervention over time?

\section{Method}

\section{Mode of Inquiry}

The study was based on an interpretivist paradigm involving understanding and interpreting meanings as revealed during interactions with the participant. I used a longitudinal, interpretive, explorative, descriptive case study design (Denzin \& Lincoln, 2000; Yin, 1984). I traced the participant's progress over a period of 21 months to gain insight and facilitate interpretation rather than merely test a hypothesis.

\section{Participant and Context}

The participant was a conveniently selected 35-year-old, midcareer, Black man, Temba (pseudonym), who felt stuck in his career and consulted me during the second half of 2013 for guidance on his choice of a career. Temba (a Pedi speaker) and his wife were looking after the child of a family member at the time of the study. After numerous visits to medical doctors and specialists, the couple had been informed that they would never be able have a child of their own. Temba had a bachelor's degree with honors in education and had taken a position at his current school in an extremely impoverished area approximately 10 years ago. When asked, Temba agreed that the results of the 
assessment could be published. I ensured Temba's well-being throughout the study. I obtained informed consent (written) from him, and guaranteed and maintained confidentiality. I took care to ensure that he understood the feedback, allowing sufficient time for clarification. I did not charge him for the counseling service.

The selection criteria called for a nondominant group member who had indicated a need for career counseling. I chose the participant because his story was representative of the stories of many thousands of Black people challenged by disadvantageteachers in particular. After multiple research projects, I have realized that tens of thousands of Black teachers in particular find themselves at a crossroads, wanting to leave the profession (for a variety of reasons), but without any idea regarding what other options are available (Maree, 2010).

\section{Procedure}

I used the CCI to elicit Temba's career-life story and to facilitate the process of career construction (Savickas, 2005) and selfconstruction (Guichard, 2009). All of Temba's responses were handwritten verbatim. Temba asked for the assessment (CCI) to be done in English because he spent most of his school life in an English school (only his first few years were spent in an Afrikaans school), taught at an English school, and spoke to his wife in English.

Temba lived approximately $20 \mathrm{~km}$ from the town where the assessment was conducted, and we agreed that the assessment would comprise three sessions (taking roughly 4 hours to complete in total). During Session 1 (1 hour), I held a general introductory interview with Temba, after which the assessment process began. I invited Temba to answer questions to clarify aspects of his life story, which he was requested to prepare before presenting for assessment. The CCI was conducted after we had become better acquainted (Session 2, 2 hours). Session 3 (1 hour) was devoted to "authorization," during which I read Temba's career-life story back to him and asked him to evaluate the outcome of the assessment; in other words, I asked him to authorize his career story (Savickas, 2011a). In Session 3, in accordance with Savickas's (2012) observation that "magic happens when we move [forward]" (p. 3), we discussed Temba's personal growth and considered various options for his future. I encouraged Temba to actively pursue the possibilities we discussed. We revisited the entire career facilitation process during this session, and I invited Temba to comment on the way in which he experienced the intervention. I conducted follow-up at regular intervals (every 4 weeks).

\section{Data Analysis and Interpretation}

I used thematic analysis to analyze the (qualitative) data obtained during the study. According to Braun and Clarke (2006), thematic analysis comprises a qualitative, inductive style 
of analysis and the "process of coding the data without trying to fit it into a pre-existing coding frame" (p. 83). I used thematic analysis to identify, analyze, and report themes and patterns and to "[describe the] data set in (rich) detail" (Braun \& Clarke, 2006, p. 79). There are six distinguishable phases in the process of analyzing data during thematic analysis: (a) familiarizing oneself with the data, which are transcribed, read, and reread; (b) generating preliminary codes systematically across the data set; (c) organizing codes into possible themes and subthemes; (d) reviewing themes and creating a thematic map of the analysis; (e) defining and labeling themes to clarify them; and (f) writing a report. For purposes of the present study, only those themes not elaborated on before in the literature (e.g., career adaptability and its subfacets, concern and control) are reported. These themes mainly pertain to self-construction (forward movement) by the participant. I recorded and interpreted responses to the CCI questions according to the eight-step guidelines proposed by Savickas (2011a) to create Temba's life portrait.

\section{Rigor of the Study}

To enhance trustworthiness of the study, I carried out peer debriefing and participant review, and reported the data verbatim. I discussed the data with a colleague who has many years of experience in qualitative data analysis, and I asked Temba to review my synthesis of interviews for correctness. I avoided selective use of the data, and, to prevent any misunderstanding, I verified all interpretations of conversations held with Temba with him. Because this was a qualitative study, I dealt with emphatic neutrality by shifting the emphasis on my neutrality as the researcher to the neutrality of the data, as recommended by Lincoln and Guba (1985).

\section{Interpreting Temba's Responses}

Temba had little difficulty identifying the themes and subthemes that emerged from his reflections. He was repeatedly asked to make connections between his life themes and different working environments with a view to actualizing these themes so that he could enter into an appropriate occupation and also make a social contribution. I impressed upon him that he was the expert on his own life and that, while listening to me read his responses back to him with minimal interpretation from me, he would be listening to his own voice.

\section{Results}

\section{Career-Life Story Responses to CCI Questions}

The CCI begins by asking the client, "How can I be useful to you?" to determine the client's counseling goals and potential solutions they may already be considering. In response to this question, Temba said: 
Help me become knowledgeable and attain more skills, take informed choices, make a difference in society. Options available to me include the following: Stay on at the school. Or seek for greener pastures by, for instance, studying further at a university. This should, however, enable me to uplift disadvantaged communities and help learners and emerging educators build futures. Possible study options include journalism, geography, and information technology. I want to be recognized for the work I have accomplished, to plough back to the community, and to achieve the highest qualifications I possibly can.

When Temba initially sought career counseling, he expressed his despondency about not being recognized for his work, as well as his frustration about neither being given opportunities for further study nor believing that the "unsatisfactory situation at my current school would ever change."

The CCI then proceeds with five questions about self (role models); setting or manifest interests (favorite magazines, TV shows, or websites); scripts for linking self to setting (favorite books or movies); self-advice (motto); and scheme, or central life problem, preoccupation, or pain (early memories). Following are Temba's responses to each one of these questions.

Role models. "A certain priest. He gave his congregation direction and always preached (and demonstrated) righteousness, kindness, trustworthiness. An older person that I saw as a father figure. I never had a father. He taught me to survive, to be independent, to look after my family, and how to become a sincere person. Jean-Claude van Damme. He showed me that if you are passionate, you will grow. He was fear- lessnever intimidated."

Favorite magazine, television show, and website. "Reader's Digest. Stories about, for instance, the Amazon basin and the hardships people are facing do not focus on individuals but rather on the world and world politics and help you understand how other people are living. This magazine gives you a true perspective on global, world politics. CNN. The world news shows how world politics are shaped, how vicious world leaders can become, how cruel some people are - they do not appreciate other people's perspectives. It opened my eyes and taught me to be down to earth, friendly, humane, sharing with others who do not have. I have seen so many people struggle so much. Facebook. I love hearing the opinions of other people, learning more about their way of perceiving things - their perspectives."

Favorite book or movie. "Dirty Dozen. A group of soldiers are taken from a prison to rescue individuals from other countries. Telly Savalas, the main character, was bold, tall, large, decisive, firm, and convincing. He had authority. An orator people would listen to, he oozed self-confidence.

He trained these guys about how to conduct warfare-taught 
them skills. He took them to do their duty. In the end, only six or seven would come back. It teaches people that the moment you indulge yourself in crime, not only God but your deeds as well will punish you. They returned and did not have to go back to prison because of having showed guts and determination. They were rewarded with another chance."

Favorite sayings or mottoes. "In God I trust." "Don't argue with a fool." "The hand that gives is the hand that receives." "Respect your elders. God will then bless you." "If at first you don't succeed, try and try again."

Three earliest recollections. The headlines of the three earliest recollections were decided on by Temba with minimal input from me.

1. "A child learns not to act short-sightedly."

"At the age of 4 years, I traveled to Pietersburg [South Africa] with my uncle. When we arrived, we had lunch. We were five kids (four of my uncle and me), eating a big dish. My uncle was fixing his car outside, and I was the first to leave the room in which we were eating. I played around in my uncle's car, which was jacked up. Without knowing that I was making a grievous mistake, I filled the oily part of the engine with soil, and then moved out of the yard to chase cattle. In less than a few minutes, I heard my uncle yelling at everyone in the yard. I knew that he had found the soil in the engine part, so I hid myself while all the other kids were looking for me. I finally came back and they asked me who had done it. I said it was a ghost: I saw the ghost do it and chased it away, which is why I was in the streets. My aunt punished me and I felt very bad."

2. "A learner pays the price for being inconsiderate."

"In Grade 3, we were given homework, namely to recite our recitation (Oom Thys de Beer van Lekkerdraai [Uncle Thys de Beer from the small town called Lekkerdraai]). When teacher pointed me out the following day to recite the poem in class, I put my own words in the poem. The whole class laughed at me, and teacher was angry with me because I was disrupting the class. The principal subsequently asked for my address but I gave them the wrong address because I was afraid of my mother. One learner said: 'Ma'am, Temba is lying.' She then gave teacher our right address. I was very angry. Teacher took the details and said they would go to our house to Mom. After school, I swore at the student, who started crying. When I went home, teacher was still at work. When I got home, even though the dogs were still outside, I decided I would not open the gate if teacher came. The following morning, though, when I arrived at school, my mother was there, too. I was wrong; the principal had gone directly to my mother. I did not receive lunch and was expected to clean the toilets." 
3. "A young man learns that aggression serves no purpose." "At the age of 7, I met a young woman, Louisa. She charmed me but I did not have the courage to tell her that. So I told a friend to give her chocolates. However, my friend ate the chocolates. I asked her if she had received the chocolates, but she said no. I was shocked. My friend and I therefore had a physical fight. Afterwards, my nose was bleeding, my shirt was torn, and the sole was detached from my shoe. I went home (to my aunt's home), but there was no one there. So I washed my face, burnt my bloodied shirt, and tried to use glue to fix my shoe. The following morning the case was reported to the school principal. Mother was again called to school and I was suspended for 2 days. This happened just before the June exam. I failed the term and mother was very upset with me. She showed me my report, grounded me, and refused to give me any money. I deeply regretted the whole thing."

\section{Life Portrait Construction}

Temba and I worked together to coconstruct his portrait according to an eight-step process (Savickas, 2011b). In Step 1, I carefully considered Temba's response to the first question in the CCI to determine his goals regarding career counseling. His response revealed his present challenges and his strategy to resolve them. Standing at a crossroads, he sought counseling on how to improve his sense of self. Temba, a driven person, was keen to further his studies but did not want people to feel that he was letting them down. He wanted to continue helping the young people in the desperately poor environment where he was teaching; he had to find a way to achieve his dual aims. He was hesitant to do anything that could take him away and deny his students and the community the opportunity to draw on his guidance as a substitute father. He wanted his own growth to positively affect his community.

In Step 2, we used Temba's earliest recollections to identify his central preoccupations. Linking the three stories with his account of his three biggest challenges when he was younger, I pointed out to him that he was a brave young man who had managed to master actively what he had suffered passively (i.e., poverty, growing up without a father, having no support structures, and having to take on responsibilities at home far beyond his years). He had managed to move from acting irresponsibly toward assuming responsibility for others and from being a victim to being a victor; converting pain into hope, hardship into resilience, and inaction into action.

In Step 3, the people Temba admired most were analyzed to determine his self-concept, central life goals, and proposed solutions to his central life problems. Temba's role models confirmed his central life goals and his proposed solution to his central life problems. He wanted to give his students direction 
through advocating and demonstrating good behavior, kindness, and trustworthiness. He is a father figure to many young people whom he teaches how to survive, work hard, be independent, look after their families, and be trustworthy.

In Step 4, I analyzed Temba's favorite magazine, TV program, and website to determine the settings or environments that best fit his lifestyle. He wants to learn about the hardships people suffer universally as well as their views on major issues to help him meet his need to assist those who are less fortunate and challenged by major disadvantage.

In Step 5, I analyzed Temba's favorite story to determine whether it contained a character with problems similar to his and, if so, how the character solved the problems and how the story's plot provides a script for Temba to link himself to work settings. Just like the main character,

Temba wants to teach his students to face challenges, do their duty, and realize the wrongness of crime. He wants to teach them that people always have another chance if they want to succeed or make amends, and that people should forgive others who have made mistakes.

In Step 6, Temba drew on his three favorite mottoes or quotations to find advice he could give himself on how to "heal" himself. He puts his trust in God, realizes that it serves little purpose to argue with people who have set views, and believes that it is in giving that we receive. He is a respectful person who maintains that resilience and a never-say-die attitude are crucial in achieving success.

In Step 7, Temba and I discussed various fields of study and occupations for job analysis.

In Step 8, I asked Temba to write a response to his original request for career counseling. He confirmed that he wanted to "escape from my current impasse but dread the idea of leaving my community behind me to go and study. I have to take them with me. Everybody must gain from what I do."

The following life portrait was coconstructed by Temba and me (Savickas, 2011a). (For easy reference, S1 refers to the first step in the creation of the life portrait, CCIQ1 refers to Temba's response to the first question in the CCI, and so on.)

(S1): "I am a driven person-a go-getter. I am ready to move forward but without making people feel that I am letting them down. I want to help the young people in the desperately poor environment in which I am teaching, which is why I am hesitant to take steps that would take me away and deny them the opportunity to draw on my guidance as a substitute father, so to speak."

(S2, CCIQ5): "I know that irresponsibility never pays. I have a great responsibility to be a role model where I live but to also give myself the opportunity to grow. I want to make up, in a sense, for my own mistakes and, in doing so, create opportunities for young people that I didn't have. 
They need not fight 'in the streets'; they can promote their cause by studying and fighting ignorance."

"I have suffered great poverty; grew up without a father; had no support structures; had to deal with difficult challenges without much support from others; and had to act responsibly at home, far beyond my years. I am a brave man who has learnt and managed to accept responsibility for many other people challenged by disadvantage."

(S3, CCIQ1): "I aspire to give my learners direction and I preach and demonstrate righteousness, kindness, and trustworthiness. I teach them to survive, to be independent, to look after their families and to become sincere people. I am independent and visionary and I want to elicit the best from my learners."

(S4, CCIQ2): "I enjoy finding out more about the hardships people are facing, focusing on the bigger picture, and learning about other people's perspectives on major challenges. This should equip me with the know-how to meet my deep-seated need to help others that are disadvantaged and less fortunate."

(S5, CCIQ3): "I want to teach learners to face challenges, do their duty, realize that crime doesn't pay, that there is always another chance if one wishes to succeed or make amends. That we should forgive others who have made mistakes."

(S6, CCIQ4): "I put my trust in God, I realize that it serves little purpose to negotiate with people who have a bunkered perspective, and I believe that it is in giving that we receive. Moreover, I am a deeply respectful person who believes that resilience and an attitude of never-saydie are vitally important if one wishes to achieve."

I then asked Temba to compose his mission statement (MS), and this is what he decided on with me: "I will complete my studies and find solutions to ever-emerging problems experienced in our education system (i.e., with poor people in general) and, in the process, enhance the quality of education of our learners (students) and become a mentor after the model of Nelson Mandela and Desmond Tutu."

I used this MS to identify the resources Temba needed to devise a feasible action strategy to realize his stated aims. Recommended fields for investigation were a master's degree in a subfield of education followed by a doctoral degree in the same subfield and/or short courses in, for example, management, life coaching (including team building), emotional-social intelligence, soccer and athletics coaching, project design, and landscaping. Because Temba received no substantial support with regard to his career-related future from, for example, either his school or his family, the impact of these factors on the outcomes can be ruled out.

The basis for these recommendations was Temba's expressed 
desire to learn about the hardships people suffer and, more importantly, help him meet this need to assist people who are less fortunate and challenged by major disadvantage. Career constructing aimed to help him by enabling him to reflect on and gain perspective on his career-life story and facilitate reflexivity. Realizing that he was a talented, respected, and compassionate human being improved his sense of self. Understanding that he would not be leaving anyone behind by studying or even moving on to a work environment which would, in fact, enable him to be even more useful to his students, colleagues, and community changed his future orientation from negative to positive and confirmed his commitment to ubuntu (connectedness).

Job analysis could include visits to educational institutions and possible employers, discussions with occupational practitioners, part-time work, work shadowing, and Internet surfing. I also referred him to study leaders at various universities to discuss the possibility of doing a master's degree in his chosen field of specialization in education. I then suggested Temba return home and consider possible options for dealing with the challenges confronting him and report back to me if and when he wanted.

\section{Results of Thematic Data Analysis}

Table 1 presents the themes and subthemes identified through thematic analysis. The main themes were hopefulness, enhanced sense of self, preserving ubuntu, and self-reflection and reflexivity. The excerpts in Table 1 suggest that participating in career construction counseling helped transform Temba's future orientation from negative (beforecareer counseling commenced) to positive. His sense of self seemed greatly enhanced, and the realization that he would be able to move forward without reneging on his deep commitment to ubuntu acted as a metaphorical green light to proceed on his career-life journey. Whereas previously he feared change, reflecting and gaining perspective on his life story facilitated reflexivity. Drawing on his career-life story made him realize that change and action would equip him with the means to heal himself and others more meaningfully and powerfully. 


\section{TABLE 1}

\section{Summary of Identified Themes and Subthemes in Clients'}

\section{Subtheme}

Responses to Career Construction

Interview Questions

Temba's Verbatim Response

Subtheme 1: Positive future orientation

Subtheme 2: Inspiration

Theme A: Hopefulness

The sessions gave me hope for the future.

I am inspired because I know what I can realistically aim for.

Theme B: Enhanced Sense of Self

Subtheme 1: Self-belief

Subtheme 2: Self-efficacy

Subtheme 3: Rewriting and coconstructing a life story

Subtheme 4: Self-respect

Subtheme 1: Preserving a sense of connectedness to others

Subtheme 2: Self- and community construction

life has helped me
It was most revealing to see that I could advise myself. Knowing where I am headed, what I want to study, and what I achieve will help me get there.

The information about my own story and about possible career choices other than the ones I knew about was enlightening. The idea of writing my story initially sounded strange but now strongly appeals to me. I have regained my sense of pride in who I am, what I mean to others, and where I am going. Redeemed myself, so to speak. I will not leave others in the lurch.

\section{Theme C: Preserving Ubuntu (Connectedness)}

I am totally relieved to know that I can take my community with me instead of leaving it behind (which was my greatest fear before I met you).

I am relieved now that I know that my students (and their families), too, will benefit from what I do.

When first we met, I felt somewhat skeptical about your novel approach. However, the sincerity and total care you demonstrated made me feel proud of myself-proud because you believed in me. I felt held.

It was a surprising experience which opened many new possibilities for me. And for my community.

Theme D: Self-Reflection and Reflexivity

Subtheme 1: Change perspective Looking back over my understand myself, given me the courage to deal with my current challenges, and given me hope for the future. My situation looks different now. Yes, things are the same on the surface; yet, inside, I have changed.

Subtheme 2: Action orientation Before we met, I felt disheartened and disempowered. Now, however, I feel capable of taking steps to escape from the hole I was in.

\section{Discussion}

The findings suggest that considering their early recollections can help individuals regain hope for the future, recover their self-esteem, and enhance their self-efficacy. Counselors can use the CCI to help clients embrace change as an opportunity for development, rekindle their hope for the future, and design more successful lives. Counselors can use the CCI to help clients recount their career-life stories, retell their stories, and in doing 
so, give them the opportunity to reconstruct and redesign their lives during periods of transition. Clients are enabled to identify major life themes and connect the many microdots that collectively comprise their career-life stories.

These findings are consistent with those of earlier studies. Whereas Del Corso, Rehfuss, and Galvin (2011) demonstrated the value of the CCI in enhancing the career adaptability of clients, Maree (2014) highlighted the value of the CCI in working with members of marginalized and minority groups. Taber and Briddick (2011) provided evidence of the value of the $\mathrm{CCI}$ in meeting the resilience adaptability needs of workers in the current world of work, and Taber, Hartung, Briddick, Briddick, and Rehfuss (2011) showcased the value of the CCI in creating life portraits to inspire hope in a brighter future.

In the present case study, the counselor merely helped the client narrate, retell, and listen to his own story. He was empowered to move forward actively and manage a crossroads in his life adaptively without leaving vulnerable others behind (a major life theme). This is confirmed by his response to my question, "How were the sessions useful to you?" He replied:

Yes, I think the first thing that springs to mind is that you have filled me with hope and joy by validating who I am, who I can be, and what my talents are. I am amazed about how much I learned about myself.

Of course, this was a limited, local study perhaps constrained by my subjective interpretation of the data. More research, especially of a longitudinal nature and with more participants, is needed to achieve the desired goal of generalizability. Successful implementation of the strategy is dependent on the professional training of career counselors in narrative traditions and orientations. Creating a "sacred space" (Savickas, 2011a) for establishing a therapeutic relationship between counselor and client is also essential for the success of this strategy.

\section{Follow-Up}

Follow-up was requested on an ongoing basis (as Temba saw fit and depending on his schedule) to monitor Temba's progress and to enable me to assess the usefulness of the intervention from Temba's perspective. It was undertaken after $1,2,4,8,12$, 16, and 21 months, respectively. The time frame was determined by Temba.

Temba reported back to me regularly on his progress, with the main theme being that recounting and listening to his life story had taught him a great deal about himself. After 12 months, he commented:

I have enrolled for my master's degree in education, and I am deeply motivated to make a huge success of my studies. Seeing myself appear in words was amazing. Seeing my studies unfold is deeply rewarding. I 
am inspired and deeply motivated to achieve at university .... as soon as possible, so I can become a lecturer at the university.

Temba reported back to me on his supervisor's feedback, confirming that he was making excellent progress. After 16 months, he informed me that he had become a part-time employee in the Distance Education program of the university where he was studying and that he had been promoted to the post of facilitator at the local district office.

After 21 months, Temba phoned me one morning. Overjoyed, he tearfully informed me that the family's general practitioner had informed his wife and him the previous day that his wife was 4 weeks pregnant. Temba attributed the pregnancy to the positive developments that had taken place in his and his wife's lives as a result of the intervention reported in this article, which, in his words, "had changed our lives immeasurably, positively, forever; had given both of us hope; and is something that both of us will cherish forever." He concluded, "Please thank the man you refer to so often [Mark Savickas], and tell him that he really works magic." At the time of this writing, Temba's wife was 6 months pregnant and doing very well.

\section{Conclusion}

Career structure, career personality, career adaptability, and life themes are generally highlighted by career counselors in the postmodern era (Savickas, 2005). Career counseling assessment and intervention should elicit career- life stories and also draw on scores to facilitate career choice, adaptability, and development. Counselors and clients should be enabled to unpack, construct, deconstruct, reconstruct, and coconstruct clients' life stories. In the current case, the usefulness of career construction counseling was demonstrated by the inspiring way in which the client turned hesitation and indecision into action and made fundamentally important choices in and changes to his life. He was empowered to deal with personal and work-related challenges and trauma and to accept authorship of his careerlife story (Savickas et al., 2009). By drawing on the multiple microfacets of his life story, he could uncover deep-seated motivations and strengths. His narratability (in other words, his ability to enunciate and listen to his career-life stories) will likely promote continuity in his life story and help to develop his sense of self-esteem and identity to enable him to engage with the world more actively and adaptively.

As the case study demonstrated, this approach to career counseling can promote clients' ability to heal themselves, design and construct successful lives, and make social contributions through their work. It can also provide practitioners with a viable theoretical and conceptual framework for understanding the unique experiences of disadvantaged individuals facing career-related crossroads. A rationale for 
future research is offered. Our aim as career counselors should be to enable clients from all walks of life-not only a privileged few who can afford this often expensive service- to construct, deconstruct, reconstruct, and coconstruct their lives and (re)write their life stories in collaboration with empathetic career counselors, and thereby move forward with hope and confidence.

\section{References}

Ali, S. R., Fall, K., \& Hoffman, T. (2014). Life without work: Understanding social class changes and unemployment through theoretical integration. Journal of Career Assessment, 21, 111-126.

Braun, V., \& Clarke, V. (2006). Using thematic analysis in psychology. Qualitative Research in Psychology, 3, 77-101.

Del Corso, J., Rehfuss, M. C., \& Galvin, K. (2011). Striving to adapt: Addressing Adler's work task in the 21st century. Journal of Individual Psychology, 67, 88-106.

Denzin, N. K., \& Lincoln, Y. S. (2000). Handbook of qualitative research (2nd ed.). London, England: Sage.

Fouad, N. A., \& Byars-Winston, A. M. (2005). Cultural context of career choice: Metaanalysis of race/ethnicity differences. The Career Development

Quarterly, 53, 223-233.

Guichard, J. (2009). Self-constructing. Journal of Vocational Behavior, 78, 251-258.

Gurri, M. (2013). The revolt of the public and the crisis of authority in the new millennium [Kindle DX version]. Retrieved from Amazon.com

Hartung, P. J. (2013). Career construction. In M. L. Savickas (Ed.), Ten ideas that changed career development (p. 11). Broken Arrow, OK: National Career Development Association.

Lincoln, Y. S., \& Guba, E. G. (1985). Naturalistic inquiry. London, England: Sage.

Maree, J. G. (2009). Career counselling in the 21st century: South African institutions of higher education at the crossroads. South African Journal of Higher Education, 23, 429-435.

Maree, J. G. (2010). Critical appraisal of the system of education and prospects of meeting the manpower and developmental needs of South Africa. Africa Insight, 40, 85-108.

Maree, J. G. (2013). Counselling for career construction: Connecting life themes to construct life portraits-Turning pain into hope. Rotterdam, Netherlands: Sense Publishers.

Maree, J. G. (2014). Career construction with a gay client: A case study. British Journal of Guidance and Counselling, 42, 436-449.

Maree, J. G., \& Molepo, J. M. (2007). Facilitating postmodern career counselling in the Limpopo Province of South Africa: A rocky ride to hope. Australian Journal of Career Counselling, 16, 62-70.

Ndebele, N. (2013). A proposalfor undergraduate curriculum reform in South Africa: The case for a flexible curriculum structure. Pretoria, South Africa: Council for Higher Education.

Pope, M. (2011). The career counseling with underserved populations model. Journal of Employment Counseling, 48, 153-156.

Savickas, M. L. (2005). The theory and practice of career construction. In S. Brown \& R. W. Lent (Eds.), Career development and counseling: Putting theory and research to work (pp. 42-70). New York, NY: Wiley.

Savickas, M. L. (2011a). Career counseling. Washington, DC: American Psychological Association. 
Savickas, M. L. (2011b). New questions for vocational psychology: Premises, paradigms, and practices. JournalofCareerAssessment, 19, 251258. doi:10.1177/1069072710395532

Savickas, M. L. (2012). Life design: A paradigm for career intervention in the 21st century. Journal of Vocational Behavior, 90, 13-19.

Savickas, M. L. (2013). The theory and practice of career construction. In S. D. Brown \& R. W. Lent (Eds.), Career development and counseling: Putting theory and research to work (2nd ed., pp. 147-186). Hoboken, NJ: Wiley.

Savickas, M. L. (2014, July). Adaptability and life story construction in young adolescents. In L. Nota (Chair), Vocational designing and prevention. Symposium conducted at the 28th International Congress of Applied Psychology, Palais Des Congres, Paris, France.

Savickas, M. L., Nota, L., Rossier, J., Dauwalder, J. P., Duarte, M. E., Guichard, J., . . . Van Vianen, A. E. M. (2009). Life designing: A paradigm for career construction in the 21 st century. Journal of Vocational Behavior, 75, 239-250.

Taber, B. J., \& Briddick, W. C. (2011). Adlerian-based career counseling in the age of protean careers. Journal of Individual Psychology, 67, 107-121.

Taber, B. J., Hartung, P. J., Briddick, H., Briddick, W. C., \& Rehfuss, M. (2011). Career style interview: A contextualized approach to career counseling. The Career Development Quarterly, 59, 274-287.

Watson, M. (2013). Deconstruction, reconstruction, co-construction: Career construction theory in a developing world context. Indian Journal of Career and Livelihood Planning, 2, 3-14.

Wijnberg, C. (2013). Youth unemployment in South Africa-There's more to it than you think. Retrieved from http://www.sagoodnews.co.za/newsletter_archive/youth_unemployment_in_south_africa_theres_more_to_it_than_you_think.html

Yin, R. K. (1984). Case study research: Design and methods. Beverly Hills, CA: Sage. 